\title{
HAPPINESS AND ECONOMIC DEVELOPMENT
}

In Happiness And Contemporary Society : Conference Proceedings Volume (Lviv, March, 20-21, 2021). Lviv: SPOLOM, 2021. P. 261-265. https://doi.org/10.31108/7.2021.58

ISBN 978-966-919-697-2 
https://doi.org/10.31108/7.2021.58

TUDORACHE Marilena Claudia

Bachelor of Science in Economics, Program of study ,Finance and Banking” Petroleum-Gas University of (Ploiesti, Romania)

\section{HAPPINESS AND ECONOMIC DEVELOPMENT}

Throughout its existence, man has tried to satisfy its needs as best he could. Therefore, he had to provide a permanent development of his activity, socially, technically, and economically to achieve the desired level of well-being. In the context of society, the well-being of the individual is influenced by the economic choices of public authorities.

Economic policy is a set of objectives and tools through which the state acts on economic variables, in order to maintain, restore or change the economic and social climate. Economic growth is a priority objective of any economic policy, because it influences the rate of employment and inflation, the level of income and welfare of the population and therefore the level of happiness of individuals.

The aim of this paper is to highlight the relationship between the idea of happiness of the individual, and the economic development of the society to which he belongs. The analysis is based on the concept of economic growth, which accompanies the economic development of any society, regardless of the degree of development.

Key words: economic development, happiness, society, income.

Introduction

Throughout its entire existence, man has tried to satisfy its needs as best he could. This process involved a set of activities designed to help him fulfill his goal. Efforts have been made by psychologists, who have dealt with what particular ingredients and circumstances make people happy or unhappy (Frey and Stutzer 2002).

Therefore, he had to achieve a permanent development of his activity, from a social, technical and economic point of view. Inevitably, man's activity of satisfying his needs presupposes the existence of a framework in which to act. Thus, man faced up with the issue of environment-economy which proved to be a global one with complex and multidimensional features.

The aim of this paper is to highlight the relationship between the idea of happiness of the individual (an ideal of any society, regardless of the degree of development) and the economic development of the society to which it belongs.

Happiness and economic growth

Happiness is considered by many people as the ultimate goal of life. And indeed most often we say about ourselves that we want to be happy. In 1776 in the United States Declaration of Independence, the pursuit of happiness was considered to be a truth so obvious about the human being that was included among inalienable rights along with the right to life and liberty.

The connection between money and happiness has been a controversial topic for thousands of years, found in proverbs, parables and advice. Due to the fact that people 
spend $50 \%$ or even more of their waking time at work, if they do not feel well there, the unhappiness will spread to the other fields of their life.

Economics is the social science that puts the individual and his needs at the center of his actions by relating to constraints. Constraints limit the room for maneuver from a social point of view, by relating to resources and can have positive as well as negative effects on an individual's well-being. Economic policy is a set of objectives and tools through which the state acts on economic variables, in order to maintain, restore or change the economic and social climate. Economic policies express the set of economic choices of the public authority, similar to the economic choices of the consumer, producer, investor, etc.

Economic growth is a priority objective of any economic policy, because it influences the rate of employment and inflation, the level of income and welfare of the population and therefore the level of happiness of individuals. In the context of an increasingly integrated global economy, economic growth results from:

- Higher productivity, by improving work efficiency, management and capital utilization in production;

- Improving market knowledge, successful strategies for market penetration and higher value-added products and services, through a dynamic entrepreneurial base;

- Effective capitalization of research results in the innovation process;

- Investments in infrastructure in order to improve accessibility and living conditions;

- Efficient administration/governance, both in the public and in the private domain, to ensure a favorable environment for investments and for a better use of public resources;

- Assuming the principles of sustainable development to ensure an efficient management of resources and environmental management.

From my point of view, economic growth is not directly proportional to people's happiness, because it can generate positive and negative effects in their lives. The cause of these effects depends strictly on the way in which the economic policies of the state affect or influence the life of each individual.

Economic growth allows the change of lifestyle, and as the income increases, the consumption model changes in order to improve the quality of life. In the long run, technological changes influence the lifestyle of an entire nation only that, in my opinion, there is not an increase of consumption, but a consumption of other goods, new products.

For economists, who usually assume that higher incomes represent a gain to the satisfaction of individuals, the role of income is of particular interest. (Deaton, 2008)

A negative impact of economic growth on the happiness of the individual can be represented by its implications on the redistribution of income. It is known that not all individuals benefit equally from economic growth. There are poor people who are not in the labor force and thus cannot have access to higher wages resulted from economic growth. Others lose their jobs as a result of technological change, and this creates unhappiness for individuals.

Any satisfaction people gain from a boost in their income tends to be eroded significantly if incomes all around them are rising just as fast. It follows that when prosperity is increasing throughout the nation as a whole, the average level of happiness will not rise correspondingly. (Bok, 2010 page 12) 
In a process of economic growth, income redistribution policies that take into account the well-being of the population are needed. If a constant part of the national income is redistributed, the standard of living of some people must decrease, generating unhappiness for them. However, when there is economic growth, only the increase of income can be redistributed, and thus income inequality is reduced without the need to decrease the income of the population, and therefore without diminishing the well-being of individuals.

Happiness and economic development

The processes of economic growth and economic development occur simultaneously, so they must be considered together. Economic growth is a quantitative process and economic development is a predominantly qualitative process. Growth and development are not goals, but means. The purpose of growth and economic development is to increase the standard of living, which attracts the well-being of the population, thus increasing the level of happiness of individuals.

Economic development does not happen on its own, and never has. Good public policy is at the core of the process of economic development. Such policy, however, operates along a 'knife edge', working within the limits and constraints of the conditions of the present, ever mindful of the mistakes of the past which have shaped the economy and society and its initial endowments. Even having put good policies into place is not enough; it also important for policy-makers to know when and how to leave them behind for even better strategies. (Cypher, 2009)

Economic development is a process of improving the standard of living and increasing the well-being of the population of developing countries, which is usually measured by increasing per capita income. Economic development is associated with the industrialization and modernization of the country and is inevitably a normative concept, almost a synonym for improvement. (Lehman, Seers 2014, pag 9)

From my point of view, economic development means economic growth accompanied by change, consisting in an upward movement of the entire social system. In other words, development can be interpreted as a tendency to achieve ideals of modernization as well as the happiness of the individual. According to studies, if the living standard of the population increases, the level of happiness of the individuals that make up the population of that country also increases, so from here a directly proportional connection between the two is highlighted.

What can individual happiness be related to?

Individual happiness of people can be reported in terms of income. Studies show that there is a direct and proportional connection between them. For example, a person is hired for a new job, and the salary is double compared to the remuneration of the old job. Obviously, this employee's income will double and the level of happiness will increase proportionally.

Higher income clearly raises happiness in developing countries, while the effect is only small if it exists at all, in rich countries. (Frey and Stutzer, 2002, p.90)

Individual happiness can be related to prices. This results in an inversely proportional relationship, as rising prices will generate a reduction in happiness and a decrease in prices will fuel the level of happiness of the individual. 
For example, if an individual enters a store and notices that a $50 \%$ discount is applied to the product they are interested in, this will increase the individual's level of happiness at that time.

Also in this context, from the point of view of the economy of a country, it can be highlighted that inflation is an inverse phenomenon proportional to the happiness of the people present in the society of that country. Inflation is a major imbalance present in the economy of any country, represented by a general increase in prices and the simultaneous decrease in the purchasing power of the national currency. When the inflation of a country increases, the purchasing power of the currency decreases and, therefore, the happiness of the population decreases. For economies with inflation rates exceeding 15 percent, there is a discrete drop in financial sector performance. (Boyd 2000)

The introduction of the single Euro currency has led to more stable prices in the EU, more business opportunities, better integrated financial markets and greater economic stability. Economic development in the EU is directly proportional to the happiness of the inhabitants of EU countries, whether they are natives or immigrants from other countries.

According to studies, many of the citizens of Eastern European countries have emigrated from their own countries to work in the Euro area, where labor is required. Eastern Europeans often choose to work in the EU because they find a job much easier compared to their country of origin.

An individual's happiness can be related to the unemployment rate of the country in which he lives. A country with a strong economic development usually has a low unemployment rate, but nowadays, during pandemic, things changed.

According to the UE situation during pandemic, in October 2020, the euro area seasonally-adjusted unemployment rate was $8.4 \%$, down from $8.5 \%$ in September 2020 and up from 7.4\% in October 2019. The EU unemployment rate was 7.6\% in October 2020, stable compared with September 2020 and up from 6.6\% in October 2019. These figures are published by Eurostat, the statistical office of the European Union. Eurostat estimates that 16.236 million men and women in the EU, of whom 13.825 million in the euro area, were unemployed in October 2020. Compared with September 2020, the number of persons unemployed decreased by 91000 in the EU and by 86000 in the euro area. Compared with October 2019, unemployment rose by 2.186 million in the EU and by 1.692 million in the euro area.

If a country has a very high unemployment rate, this generates unhappiness for the population, a state of fear, a great difficulty in finding a job and receiving a salary to meet their needs. The higher the unemployment rate, the higher the population's concern about the availability of jobs, the greater the uncertainty about the future and the lower the level of happiness of individuals.

By economic growth is meant an increase in production based exclusively on quantitative change, the primary factors of production which are: means of labor and labor force. There is only one way or one solution available to a country to expand its production, namely investments. These are the main factor of economic growth and are based on two main sources: population savings and external loans. For an effective economy, it is necessary for the savings to be transformed into investments. This 
depends on the interest rate on loans, the evolution of prices, public investment, fiscal policy and economic stability.

In my opinion, the happiness of the population can be related to the level of investments. Whether they are meant to extend the production of a country, or meant for research-development, education, training, vocational training or environmental protection, all investments aim at economic development, which aims at the well-being of the individual and thus increase his level of happiness.

For example, if a country has a well-developed education system, which results in highly trained researchers, this can make a beneficial contribution to the technical and innovative progress of that country. The more countries invest in human resources, the more likely they are to grow economically in the future.

Conclusion

As of March 2020, Finland was ranked the happiest country in the world three times in a row, according to the World Happiness Report of the United Nations Sustainable Development Solutions Network while Romania was ranked 47th.

The rankings of national happiness are based on respondent ratings of their own lives, which the report also correlates with various (quality of) life factors.

In conclusion, happiness as a state of mind, happiness as satisfaction in life, happiness as an impact on society - all can be goals of economic development and can be promoted through economic policies to achieve the desired level of happiness of the population.

\section{REFERENCES}

Bok, Derek C. (2010) „, The politics of Happiness :what government can learn from the new research on well-being', Princeton University Press, page 12;

Boyd J., Levine R.(2000), Smith B. „The impact of inflation on financial sector performance,", University of Minnesota, Minneapolis;

Cypher, James M. (2009) „,The process of economic development”, Routledge ;

Deaton, Angus. (2008). "Income, Health, and Well-Being around the World: Evidence from the Gallup World Poll." Journal of Economic Perspectives, 22 (2), Princeton University Press page :

Frey, Bruno, S., and Alois Stutzer. (2002). "What Can Economists Learn from Happiness Research?" Journal of Economic Literature, 40 (2): 402-435;

Frey B., Stutzer A.(2002) „Happiness and Economics: how the economy and institutions affect human well-being", Princeton University Press;

Gordon, Robert J.(2004) „Productivity growth, inflation, and unemployment: the collected essays of Robert J. Gordon'”, Cambridge University Press;

Lehman, D. Seers, D (2014) „Development theory: four critical studies”, Volume 104, Routledge 2014. 